\title{
Analisis Maintenance Quayside Container Crane Dengan Metode Failure Mode And Effect Analysis ( Fmea)
}

\author{
Ponidi $^{1 *}$, Bambang $\mathbf{P}^{2}$ \\ 1,2, Program Study Teknik Mesin Universitas Muhammadiyah Surabaya \\ Email: *ponidi@ft.um-surabaya.co.id, ponidi_72@yahoo.com
}

\begin{abstract}
Quayside container crane is a type of crane that is placed on the dock at a container terminal that handles loading and unloading of containers from ship to dock or from dock to ship. Quayside container crane is composed of structural parts, mechanical components, electrical components and control systems. This research was conducted to find the root of the problem in the Quayside container crane, by analyzing the system that was experiencing breakdown maintenance. The data used was a breakdown history Quayside container crane No. 01 in 2018-2019 at the Patchouli Terminal of Tanjung Perak Port. The analysis methods used are Fault Tree Analysis (FTA) and Failure Mode and Effect Analysis (FMEA). From the results of the analysis carried out, it was found that a list of failures that caused the breakdown in 2018-2019 consisted of supply electrical power systems, main hoisting systems, spreader systems, gantry traveling systems, maintrolley traveling systems, and boom hoisting systems. The solution to reduce breakdowns that have occurred is by implementation of predictive maintenance, preventive maintenance, and repair of SOPs and annual maintenance contracts. By using quantitative analysis using Failure Mode and Effect Analysis (FMEA), the largest Risk Priority Number (RPN) is obtained on the main trolley travel system of 450, then continued by the gantry traveling system. 360, the main hoisting system is 280, the suplying electrical power system is 294 and the boom hoist system is 42 . Based on the results of the Pareto diagram, the cumulative percentage of priority breakdown calculations is $83 \%$ of the main trolley travel system damage,
\end{abstract}

Keywords: Quayside Container Crane, FMEA, Maintenance

\section{PENDAHULUAN}

Pelabuhan adalah tempat yang terdiri atas daratan dan atau perairan dengan batas batas tertentu sebagai tempat kegiatan pemerintahan dankegiatan pengusahaan yang dipergunakan sebagai tempat kapal bersandar, naik turun penumpang dan bongkar muat barang, berupa terminal dan tempat berlabuh kapal yang dilengkapi dengan fasilitas keselamatan dan keamanan pelayaran dan kegiatan penunjang pelabuhan serta sebagai tempat perpindahan intra dan antar moda transportasi. Kepelabuhanan adalah segala sesuatu yang berkaitan dengan pelaksanaan fungsi pelabuhan untuk menunjang kelancaran, kemanan dan ketertiban arus lalu lintas kapal, penumpang atau barang, keselamatan dan keamanan berlayar, tempat perpindahan intra atau antarmoda serta mendorong perekonomian nasional dan daerah dengan tetap memperhatikan tata ruang wilayah.

Quayside container crane adalah jenis crane yang ditempatkan di dermaga pada suatu terminal kontainer yang menangani kegiatan bongkar muat kontainer dari kapal ke dermaga atau dari dermaga ke kapal.Quayside container crane tersusun dari bagian-bagian struktur, komponen mekanikal, komponen elektrikal dan sistem pengendali.Quayside container crane memiliki 4 (empat) gerakan utama, yaitu gerakan melintas sepanjang rel di dermaga disebut gerakan gantry, gerakan melintas sepanjang rel yang berada di girder crane dari sisi darat ke sisi laut atau sebaliknya untuk menjangkau kontainer disebut gerakan trolley, gerakan mengangkat dan menurunkan kontainer dengan peralatan tambahan spreaderdisebut gerakan hoisting/lowering, gerakan menaikkan dan menurunkan girder saat quayside container crane akan beroperasi/stand by disebut gerakan boom. 


\section{Jurnal Rekayasa Material, Manufaktur dan Energi}

Dari hasil data laporan pemeliharaanquayside container crane 01 tahun 2018-2019 di Terminal Nilam Pelabuhan Tanjung Perak, ditemukan bahwaalat tersebut sering mengalami kegagalan fungsi dalam kegiatan operasi sehingga mengakibatkan terganggunya kegiatan produksi bongkar muat petikemas.Maka dari itu perlu dilakukan evaluasi pada sistem perawatan yang sudah berjalan untuk mengevaluasi kegagalan-kegagalan yang terjadi. Daftar kegagalan yang menyebabkanbreakdownpada tahun 2018-2019 terdiri darisupply electrical power system selama 121 jam, main hoisting system selama 54,5 jam, spreader system selama 19 jam,gantry traveling system selama 82,5 jam, main trolley traveling system selama 1341,5 jam, danboom hoisting system selama 3,5 jam.

Quayside containercrane nomor 01 merupakan salah satu dari 4 (empat) QCC yang dimiliki oleh Terminal Nilam yang memiliki spesifikasi sebagai berikut :

Merk/Pembuat

Tahun Pembuatan

Safety working load (SWL)

Model

Power
: Mitsubishi Heavy Industri Ltd

$: 1995$

: 35 Ton (under spreader)

: Panamax

: Electric 3 phase, 660 volt, $60 \mathrm{~Hz}$

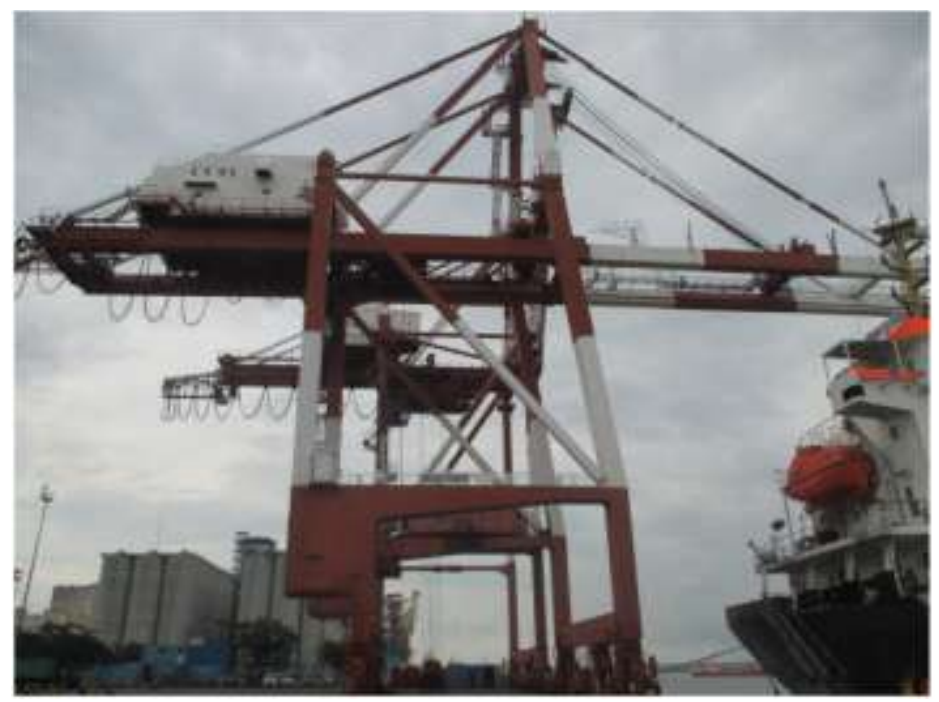

Gambar 1. Quayside Container Crane- 01

Konstruksi QCC tidak hanya sekedar menyamai perubahan dalam teknologi perkapalan, akan tetapi spesifikasi maupun performasi crane berubah menjadi semakin besar, cepat dan semakin andal. Perubahan telah terjadi sangat signifikan dalam box rate atau load and discharging rate yakni pada kecepatan 40 sampai 55 boxes per jam, atau dengan kata lain meningkat menjadi dua kali lebih cepat dari pada sebelumnya. Peningkatan begitu tajam dicapai dengan QCC yang dilengkapi dengan second trolley system. Crane yang mempunyai dua trolley membagi tugas dengan cara trolley pertama untuk siklus kapal menghubungkan kapal dengan sebuah platform dan trolley kedua untuk siklus darat menghubungkan platform tersebut dengan bak chassis di dermaga. Secondtrolley menyingkat waktu siklus (cycle) time trolley dengan sinkronisasi gerakan antara trolley pertama dan kedua. Dari sisi operasional terdapat tiga dimensi kritis sebuah QCC yakni kapasitas angkat (hoisting) capacity, jarak jangkau (outreach), dan tinggi angkat (air height).

Hositing atau lifting capacity adalah daya angkat aman maksimal atau safe working load (swl) di bawah spreader(under spreader) yang berkisar antara 35-40 ton. SWL dibutuhkan lebih besar jikalau petikemas yang dilayani berukuran $45^{\prime}$ atau $48^{\prime}$. Outreach adalah ukuran jarak dari kaki sisi laut sampai terjauh dari trolley untuk mengangkat muatan petikemas. Outreach sebuah QCC harus sesuai dengan lebar badan kapal. Untuk memastikan jarak jangkau suatu crane, maka outreach operasional lebih tepat, yaitu ukuran jarak dari pinggir dermaga sisi laut. Outreach 
operasional adalah sama dengan outreach dikurangi jarak sisi laut ke pinggir dermaga sisi laut.Air height adalah ukuran tinggi sisi bawah spreader dalam posisi teratas dari garis permukaan air. Ketinggian tersebut berubah-ubah sesuai dengan perubahan pasang surut. Lift heigh adalah ukuran tinggi sisi bawah spreader dalam posisi teratas ke petikemas yang akan diangkat dari/ke slot tertentu. Lift heigh di atas lantai dermaga sekitar 30 meter, sedangkan untuk kapal tipe post panamax dengan muatan 5 stack di atas dek dan 9 stack di bawah dek total mencapai sekitar 47 meter.

\section{Fault Tree Analysis (FTA)}

Fault Tree Analysis adalah suatu teknik yang digunakan untuk mengidentifikasi resiko yang berperan terhadap terjadinya kegagalan. Metode ini dilakukan dengan pendekatan yang bersifat top down, yang diawali dengan asumsi kegagalan atau kerugian dari kejadian puncak (top event) kemudian merinci sebab-sebab suatu top event sampai pada suatu kegagalan dasar (root cause). Fault Tree Analysis merupakan metoda yang efektif dalam menemukan inti permasalahan karena memastikan bahwa suatu kejadian yang tidak diinginkan atau kerugian yang ditimbulkan tidak berasal pada satu titik kegagalan.Fault Tree Analysis mengidentifikasi hubungan antara faktor penyebab dan ditampilkan dalam bentuk pohon kesalahan yang melibatkan gerbang logika sederhana.Gerbang logika menggambarkan kondisi yang memicu terjadinya kegagalan, baik kondisi tunggal maupun sekumpulan dari berbagai macam kondisi. Konstruksi dari Fault Tree Analysis meliputi gerbang logika yaitu gerbang $A N D$ dan gerbang $O R$. Setiap kegagalan yang terjadi dapat digambarkan ke dalam suatu bentuk pohon analisa kegagalan dengan mentransfer atau memindahkan komponen kegagalan ke dalam bentuk simbol (Logic Transfer Components) dan Fault Tree Analysis.

\section{Failure Mode And Effect Analysis (FMEA)}

Secara etimologi, FMEA tersusun dari kata Failure (Kegagalan) Mode (Bentuk) Effect (Akibat) and Analysis (Analisa). Sedangkan secara epistimologi, definisi FMEA sebagaimana disebutkan dalam QS : 9000 adalah suatu pendekatan sistematis untuk mengenal dan mengevaluasi potensi-potensi kegagalan dari suatu produk (proses) dan akibat dari kegagalan yang ditimbulkannya.

Jenis-jenis metode FMEA memiliki 3 jenis pengembangan yang mempunyai fokus yang berbeda dalam mengeleminasi atau mengurangi potensial poin kegagalan, antar lain:

a. Design Failure Mode and Effect Analysis (D-FMEA)

D-FMEA adalah suatu teknik analisa yang pokok digunakan oleh tim desain atau pengembangan produk untuk mengetahui atau memastikan potensial poin kegagalan dan menggabungkan macam-macam penyebab untuk mengidentifikasi, mempertimbangkan, dan fokus terhadap kualitas yang dituju..

Aktifitas utama dalam mengembangkan D-FMEA adalah melakukan semua kegiatan pengembangan desain yang diinginkan konsumen dan tidak melakukan tindakan yang tidak diinginkan konsumen.Dengan ini dapat diartikan bahwa D-FMEA hanya mengevaluasi desain yang sesuai dengan permintaan konsumen. Dalam D-FMEA juga diperbolehkan melakukan sebuah alternatif pengembangan produk, selama nilai dari permintaan konsumen akan kualitas produk tidak berpengaruh.

b. Machine Failure Mode And Effect Analysis(M-FMEA)

M-FMEA adalah sebuah metode yang membuat standarisasi teknik dalam penggunaan mesin dan peralatan selama proses produksi untuk meningkatkan keselamatan operator mesin, keandalan mesin, dan ketahanan mesin. 


\section{Jurnal Rekayasa Material, Manufaktur dan Energi}

Aktifitas yang paling utama dalam menganalisa kegiatan M-FMEA adalah mempelajari pola dari karakteristik mesin, pengoperasian yang aman, pemeliharaan yang tepat, dan kegagalan yang terjadi.

c. Process Failure Mode and Effect Analysis (P-FMEA)

P-FMEA adalah sebuah kegiatan mengidentifikasi proses produksi yang kritikal dan karakteristik proses yang penting dan keduanya dijadikan buah titik awal dalam rencana untuk mengontrol proses agar tidak terjadi kegagalan.

\section{METODE PENELITIAN}

\section{Flow Chart Penelitian}

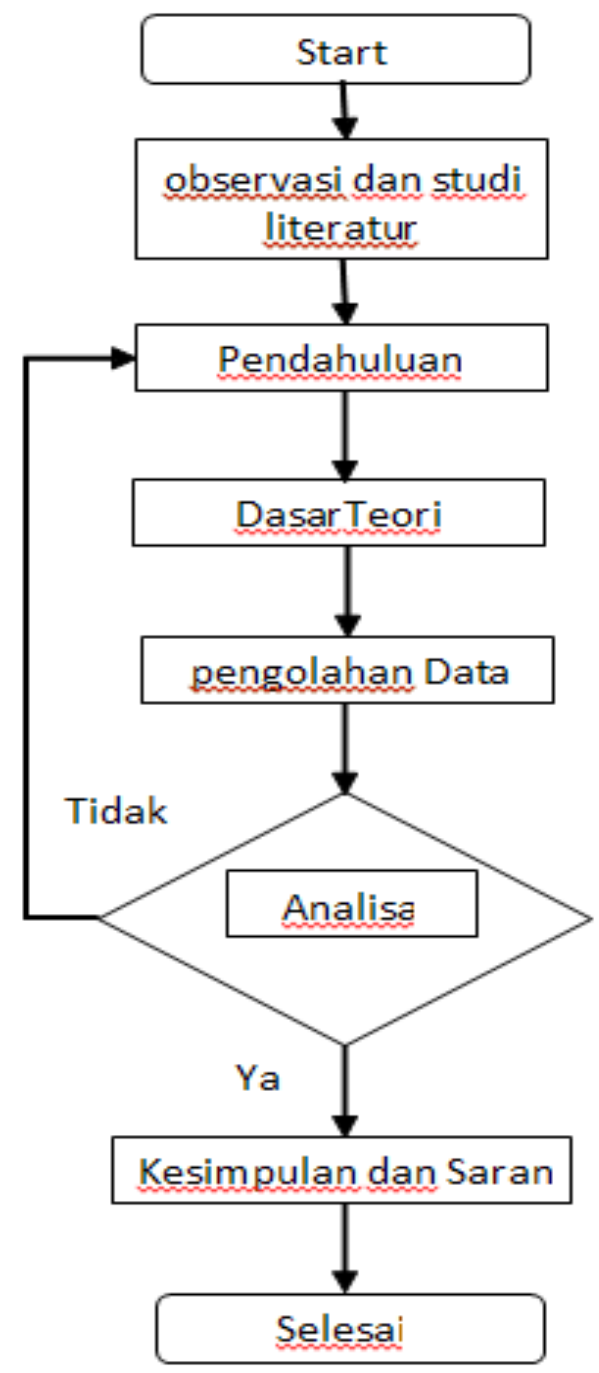

Gambar 2. Flow Chart Penelitian

Observasi awal dan studi literatur adalah langkah pertama yang dilakukan dalam penulisan laporan penelitian ini. Pada fase ini peneliti mempelajari tentang jenis alat quayside container crane, standar-standar pemeliharaan yang digunakan, hasil laporan pemeliharaan quayside container crane nomor 01, teori tentang Fault Tree Analysis (FTA), dan teori tentang Failure Mode and Effect Analysis (FMEA). 


\section{Jurnal Rekayasa Material, Manufaktur dan Energi}

\section{Pengumpulan Data}

Tabel 1. Teknik Pengumpulan Data

\begin{tabular}{|c|c|c|c|}
\hline No & Jenis data & $\begin{array}{c}\text { Metodepengambilanda } \\
\text { ta }\end{array}$ & Sumberdata \\
\hline 1 & $\begin{array}{l}\text { Histori } \\
\text { jenis-jenis } \\
\text { kerusakan }\end{array}$ & $\begin{array}{l}\text { Pengolahan data dari } \\
\text { laporan pemeliharaan }\end{array}$ & $\begin{array}{l}\text { PT Pelabuhan Indonesia III } \\
\text { (Persero) Regional Jawa Timur }\end{array}$ \\
\hline 2 & $\begin{array}{l}\text { Menentukan Deteksi } \\
\text { pada FMEA }\end{array}$ & Brainstorming/ Wawancara & $\begin{array}{l}\text { Divisi Teknik PT Pelabuhan } \\
\text { Indonesia III (Persero) Regional } \\
\text { Jawa Timur }\end{array}$ \\
\hline
\end{tabular}

\section{HASIL PENELITIAN DAN PEMBAHASAN}

\section{Fault Tree Analysis (FTA)}

Diagram FTA dibuat berdasarkan 6 risiko kritis. FTA merupakan sebuah model grafis yang terdiri dari beberapa kombinasi kesalahan (fault) secara pararel dan secara berurutan yang mungkin menyebabkan awal dari failure event yang sudah ditetapkan.Top event pada FTA ini adalah kerusakan pada sistem quayside containercrane, kemudian dilakukan analisa sehingga diperoleh basic event penyebab kerusakan yang terjadi pada sistem quayside containercrane. Berikutadalahgambarfaulttreeanalysisdari penyebab terjadinya kerusakan pada sistem quayside container crane.

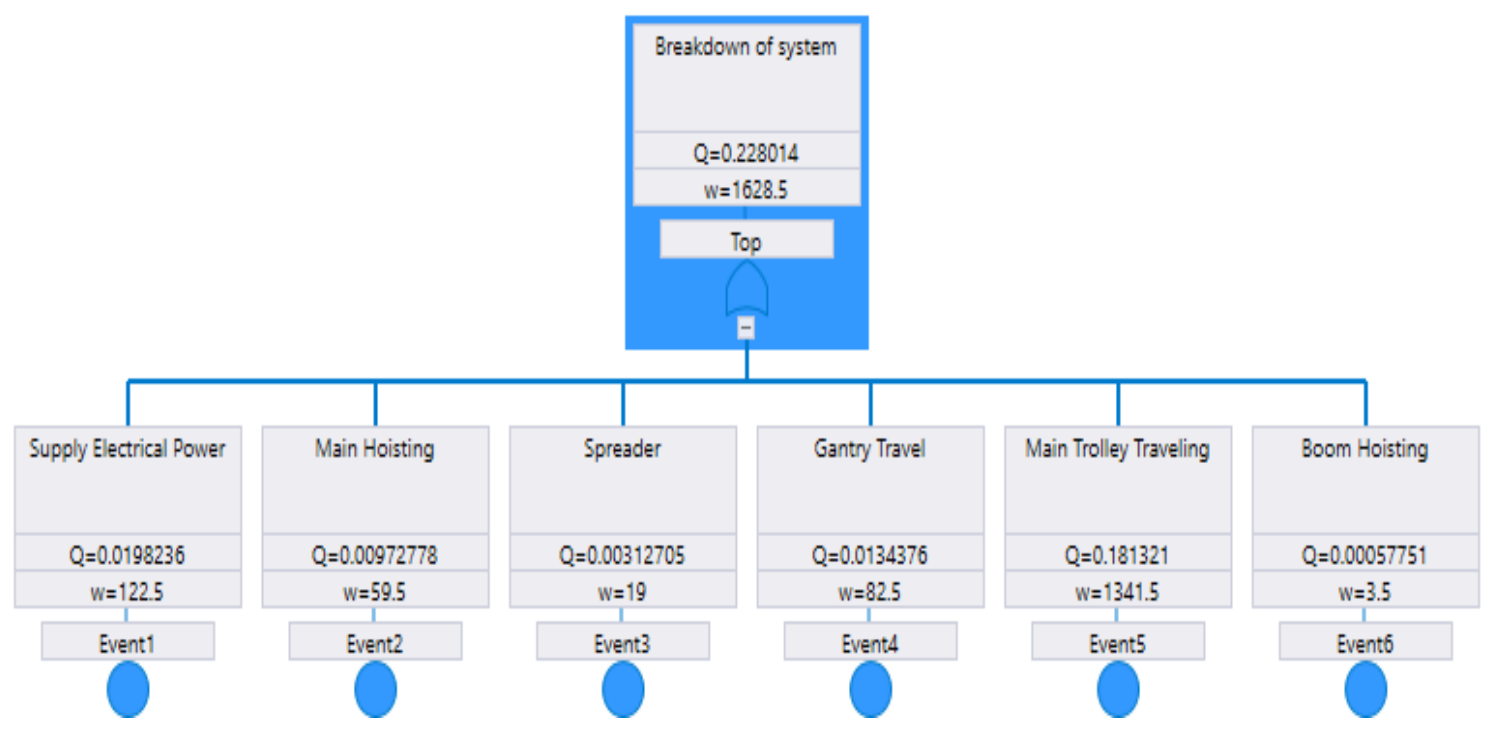

Gambar 3. Diagram fault tree analysis kerusakan pada sistem quayside container crane 01

Analisis kualitatif adalah untuk mendapatkan kombinasi kegagalan yang menyebabkan top event pada suatu sistem atau minimal cut set itu sendiri. Hasil analisis kualitatif dari moda kegagalan kerusakan pada sistem quayside container crane adalah:

1. Kerusakan pada supply electrical power.

2. Kerusakan pada main hoisting.

3. Kerusakan pada spreader.

Copyright $^{\circledR} 2020$ Jurnal Rekayasa Material, Manufaktur dan Energi. This is an open acces article under the CC-BY-SA lisence (https://creativecommons.org/licenses/by-sa/4.0/). 


\section{Jurnal Rekayasa Material, Manufaktur dan Energi}

4. Kerusakan pada gantry travel.

5. Kerusakan pada main trolley traveling.

6. Kerusakan pada boom hoisting.

Tabel 2. Daftar Minimal Cut Set 5 Risiko Kritis

\begin{tabular}{|c|c|c|c|c|c|}
\hline No & Sistem & Failure Mode & Unavalibility & $\begin{array}{l}\text { Number } \\
\text { of Failure }\end{array}$ & $\begin{array}{l}\text { \% Total } \\
\text { Failure }\end{array}$ \\
\hline 1 & $\begin{array}{l}\text { Supplying } \\
\text { electrical power }\end{array}$ & $\begin{array}{l}\text { Sistem kehilangan } \\
\text { power }\end{array}$ & 0,01982361 & 28 & $45,16 \%$ \\
\hline 2 & Main hoisting & $\begin{array}{l}\text { Sistem hoist tidak } \\
\text { dapat beroperasi }\end{array}$ & 0,00972778 & 12 & $19,35 \%$ \\
\hline 3 & Spreader & $\begin{array}{l}\text { Sistem spreader } \\
\text { tidak dapat } \\
\text { beroperasi }\end{array}$ & 0,00312705 & 10 & $16,13 \%$ \\
\hline 4 & Gantry traveling & $\begin{array}{l}\text { Sistem gantry tidak } \\
\text { dapat beroperasi }\end{array}$ & 0,01343757 & 6 & $9,68 \%$ \\
\hline 5 & $\begin{array}{l}\text { Main trolley } \\
\text { traveling }\end{array}$ & $\begin{array}{l}\text { Sistem trolley tidak } \\
\text { dapat beroperasi }\end{array}$ & 0,181320537 & 5 & $8,06 \%$ \\
\hline 6 & Boom hoisting & $\begin{array}{l}\text { Sistem boom tidak } \\
\text { dapat beroperasi }\end{array}$ & 0,00057751 & 1 & $1,61 \%$ \\
\hline
\end{tabular}

Analisis kuantitatif dilakukan untuk menaksir kemungkinan atau probablitas dari kejadian yang dianalisa. Berikut adalah hasil probabilitas dari minimal cut set risiko kritis kerusakan pada sistem quayside container crane:

1. Kerusakan pada supply electrical power sebesar 0,01982361

2. Kerusakan pada main hoisting sebesar 0,00972778

3. Kerusakan pada spreader sebesar 0,00312705

4. Kerusakan pada gantry travel sebesar 0,01343757

5. Kerusakan pada main trolley traveling sebesar 0,181320537

\section{Failure Mode and Effect Analysis (FMEA)}

Dari data kerusakan prioritas yang telah diperoleh, kemudian dilanjutkan dengan menentukan kegagalan fungsi, modus kegagalan, dan efek kegagalan yang terjadi. Efek kegagalan didefinisikan sebagai dampak dari failure yang terjadi. Failure Modeand Effect Analysis (FMEA) digunakan untuk melihat proses bagaimana yang paling dominan menghasilkan kegagalankegagalan. Selanjutnya yang dilakukan adalah membuat tabel FMEA yang berfungsi untuk memberikan pembobotan pada nilai Occurane $(O)$, Severity $(S)$ danDetection $(D)$ berdasarkan potensi efek kegagalan, penyebab kegagalan untuk menghasilkan nilai Risk Priority Number (RPN). Tabel FMEA dapat dilihat pada table dibawah ini : 


\section{Jurnal Rekayasa Material, Manufaktur dan Energi}

Tabel 3. Tabel Occurrence, Severity, Detection, dan Risk Priotity Number (RPN) untuk tiap risiko

\begin{tabular}{|c|c|c|c|c|c|c|c|c|c|}
\hline \multirow{2}{*}{ No } & \multirow{2}{*}{ Sistem } & \multirow{2}{*}{$\begin{array}{l}\text { Failure } \\
\text { Mode }\end{array}$} & \multirow{2}{*}{$\begin{array}{l}\text { Effect of } \\
\text { Failure }\end{array}$} & \multirow{2}{*}{$\begin{array}{l}\text { Cuse of } \\
\text { Failure }\end{array}$} & \multicolumn{4}{|c|}{ Analisa Kekritisan } & \multirow{2}{*}{ Rekomendasi } \\
\hline & & & & & $\mathbf{S}$ & $\mathbf{O}$ & D & $\mathbf{R P N}$ & \\
\hline 1 & $\begin{array}{l}\text { Supplying } \\
\text { electrical power }\end{array}$ & $\begin{array}{l}\text { Sistem } \\
\text { kehilangan } \\
\text { power }\end{array}$ & $\begin{array}{l}\text { Crane tidak } \\
\text { dapat } \\
\text { beroperasi }\end{array}$ & $\begin{array}{c}\text { Komponen } \\
\text { elektrikal } \\
\text { kehilangan } \\
\text { daya } \\
\end{array}$ & 7 & 7 & 6 & 294 & $\begin{array}{l}\text { Corrective } \\
\text { Maintenance }\end{array}$ \\
\hline 2 & Main hoisting & $\begin{array}{l}\text { Sistem hoist } \\
\text { tidak dapat } \\
\text { beroperasi }\end{array}$ & \begin{tabular}{|l} 
Sistem hoist \\
tidak dapat \\
mengangkat \\
dan \\
menurunkan \\
kontainer \\
\end{tabular} & $\begin{array}{l}\text { Kerusakan } \\
\text { sistem hoist }\end{array}$ & 8 & 7 & 5 & 280 & $\begin{array}{l}\text { Preventive } \\
\text { Maintenance, } \\
\text { Corrective } \\
\text { Maintenance }\end{array}$ \\
\hline 3 & Spreader & \begin{tabular}{|l|} 
Sistem \\
spreader tidak \\
dapat \\
beroperasi
\end{tabular} & \begin{tabular}{|l} 
Sistem \\
spreader tidak \\
dapat \\
mengangkat \\
dan \\
menurunkan \\
kontainer \\
\end{tabular} & $\begin{array}{c}\text { Kerusakan } \\
\text { sistem spreader }\end{array}$ & 6 & 7 & 5 & 210 & $\begin{array}{l}\text { Preventive } \\
\text { Maintenance, } \\
\text { Corrective } \\
\text { Maintenance }\end{array}$ \\
\hline 4 & Gantry traveling & $\begin{array}{l}\text { Sistem gantry } \\
\text { tidak dapat } \\
\text { beroperasi }\end{array}$ & $\begin{array}{l}\text { Sistem gantry } \\
\text { tidak dapat } \\
\text { menggerakkan } \\
\text { crane ke } \\
\text { kanan dan ke } \\
\text { kiri lintasan rel }\end{array}$ & $\begin{array}{l}\text { Kerusakan } \\
\text { sistem gantry }\end{array}$ & 10 & 6 & 6 & 360 & $\begin{array}{l}\text { Preventive } \\
\text { Maintenance, } \\
\text { Corrective } \\
\text { Maintenance }\end{array}$ \\
\hline 5 & $\begin{array}{l}\text { Main trolley } \\
\text { traveling }\end{array}$ & $\begin{array}{l}\text { Sistem trolley } \\
\text { tidak dapat } \\
\text { beroperasi }\end{array}$ & $\begin{array}{l}\text { Sistem trolley } \\
\text { tidak dapat } \\
\text { menggerakkan } \\
\text { kontainer ke } \\
\text { depan dan ke } \\
\text { belakang pada } \\
\text { rel trolley }\end{array}$ & $\begin{array}{l}\text { Kerusakan } \\
\text { sistem trolley }\end{array}$ & 10 & 5 & 9 & 450 & $\begin{array}{l}\text { Preventive } \\
\text { Maintenance, } \\
\text { Corrective } \\
\text { Maintenance }\end{array}$ \\
\hline 6 & Boom hoisting & $\begin{array}{l}\text { Sistem boom } \\
\text { tidak dapat } \\
\text { beroperasi }\end{array}$ & $\begin{array}{l}\text { Sistem boom } \\
\text { tidak dapat } \\
\text { dinaikkan dan } \\
\text { diturunkan }\end{array}$ & $\begin{array}{l}\text { Kerusakan } \\
\text { sistem boom }\end{array}$ & 7 & 1 & 6 & 42 & $\begin{array}{l}\text { Preventive } \\
\text { Maintenance, } \\
\text { Corrective } \\
\text { Maintenance } \\
\end{array}$ \\
\hline
\end{tabular}

BerdasarkanFMEAyangtelahdiberikanpembobotannilai,selanjutnyapadatahapinidilakukanp engurutannilaiberdasarkandarinilaitertinggihingganilaiyangterendah.Pengurutannilaidapatdilihatpa databel dibawahini:

Tabel 4. Tabel rangking tertinggi Risk Priotity Number (RPN)

\begin{tabular}{cllllll}
\hline \multirow{2}{*}{ No } & Sistem & \multicolumn{1}{c}{ Failure Mode } & \multicolumn{4}{c}{ Analisa Kekritisan } \\
\hline 1 & $\begin{array}{l}\text { Main trolley } \\
\text { traveling }\end{array}$ & $\begin{array}{l}\text { Sistem trolley tidak dapat } \\
\text { beroperasi }\end{array}$ & 10 & 5 & 9 & 450 \\
\hline 2 & $\begin{array}{l}\text { Gantry } \\
\text { traveling }\end{array}$ & $\begin{array}{l}\text { Sistem gantry tidak dapat } \\
\text { beroperasi }\end{array}$ & 10 & 6 & 6 & 360 \\
\hline
\end{tabular}

Copyright $^{\circledR} 2020$ Jurnal Rekayasa Material, Manufaktur dan Energi. This is an open acces article under the CC-BY-SA lisence (https://creativecommons.org/licenses/by-sa/4.0/). 


\begin{tabular}{|c|c|c|c|c|c|c|}
\hline \multirow{2}{*}{ No } & \multirow{2}{*}{ Sistem } & \multirow{2}{*}{ Failure Mode } & \multicolumn{4}{|c|}{ Analisa Kekritisan } \\
\hline & & & $\mathbf{S}$ & $\mathbf{O}$ & D & RPN \\
\hline 3 & Main hoisting & $\begin{array}{l}\text { Sistem hoist tidak dapat } \\
\text { beroperasi }\end{array}$ & 8 & 7 & 5 & 280 \\
\hline 4 & $\begin{array}{l}\text { Supplying } \\
\text { electrical power }\end{array}$ & Sistem kehilangan power & 7 & 7 & 6 & 294 \\
\hline 5 & Boom hoisting & $\begin{array}{l}\text { Sistem boom tidak dapat } \\
\text { beroperasi }\end{array}$ & 7 & 1 & 6 & 42 \\
\hline 6 & Spreader & $\begin{array}{l}\text { Sistem spreader tidak dapat } \\
\text { beroperasi }\end{array}$ & 6 & 7 & 5 & 210 \\
\hline
\end{tabular}

\section{Data Waktu Breakdown}

Dari tabel kerusakan dan dampak kerusakan yang telah diidentifikasi, kemudian dilakukan perhitungan prosentase downtime dan prosentase komulatif downwtime. Hasil prosentase downtime dan prosentase komulatif downtime dilakukan analisis dengan diagram paretto.]

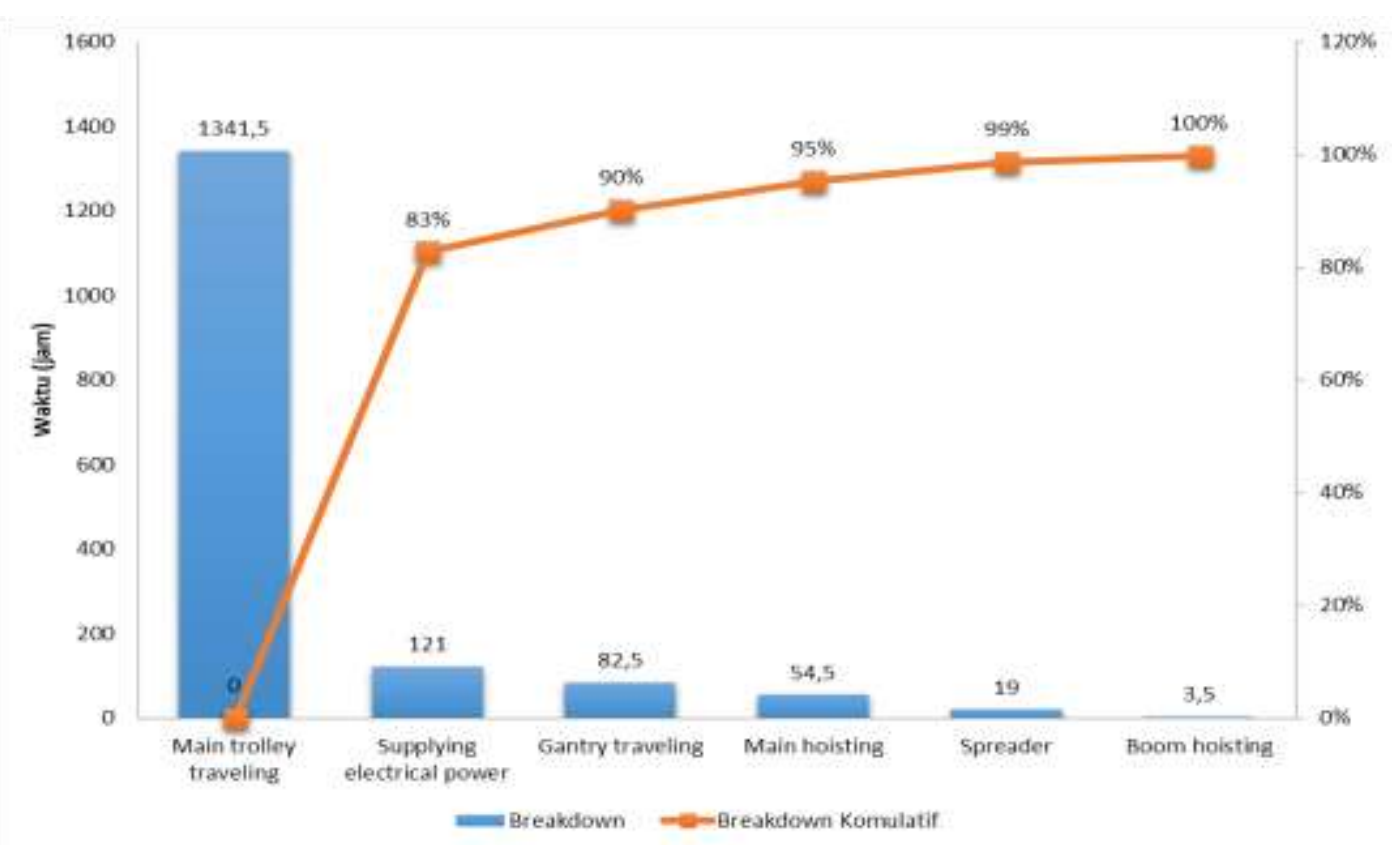

Gambar 4. Diagram pareto breakdown yang terjadi pada quayside container crane 01

Berdasarkan pengolahan data menggunakan konsep pareto, kerusakan yang menjadi prioritas utama dalam penentuan penaganan perbaikannya adalah kerusakan yang terjadi pada sistem main trolley traveling.

\section{Data Potensi Kehilangan Pendapatan}

Rata-rata pendapatan per bulan kegiatan bongkar muat quayside container crane 01 di Terminal Nilam Pelabuhan Tanjung Perak adalah Rp. 2.030.013.709,-. Rata-rata biaya per bulan yang dikeluarkan adalah Rp. 402.088.183 yang terdiri atas biaya pembayaran operator, biaya bahan bakar minyak atau biaya listrik, biaya jasa dan spare part maintenance, serta biaya depresiasi. Rata-rata laba rugi yang diperoleh Terminal Nilam Pelabuhan Tanjung Perak selama satu bulan sebesar Rp. 1.627.925.525,-. Rata-rata produksi bongkar muat quaysidecontainer 


\section{Jurnal Rekayasa Material, Manufaktur dan Energi}

crane 01 selama satu bulan sebanyak 5.128 box.Rata-rata produksi bongkar muat selama satu jam adalah 20 box container. Potensi kehilangan pendapatan bongkar muat 1 box unit container adalah Rp. 317.449,- Apabila alat tidak dapat beroperasi selama 1 jam, maka potensi kehilangan pendapatan kegiatan bongkar muat adalah sebesar Rp. 6.322.201,-

Tabel 5. Tabel potensi kehilangan pendapatan

\begin{tabular}{clr}
\hline No & \multicolumn{1}{c}{ Uraian } & \multicolumn{1}{c}{ Nilai } \\
\hline 1 & Rata-rata pendapatan/bulan (Rp.) & 2.030 .013 .709 \\
2 & Rata-rata biaya/bulan (Rp.) & 402.088 .183 \\
& Operator & 50.168 .335 \\
& BBM/Listrik & 42.994 .495 \\
& Maintenance & 133.363 .558 \\
& Depresiasi & 175.561 .796 \\
3 & Rata-rata Laba Rugi/bulan (Rp.) & 1.627 .925 .525 \\
4 & Rata-rata produksi/box/bulan (box) & 5.128 \\
5 & Potensi kehilangan/box (Rp.) & 317.449 \\
6 & Produksi/jam (box) & 20 \\
7 & Potensi kehilangan /jam (Rp.) & 6.322 .201 \\
\hline
\end{tabular}

\section{Analisa Kegagalan}

Berdasarkan pengolahan data yang telah dilakukan dengan menggunakan metode Fault Tree Analysis (FTA), Failure Mode And Effect Analysis (FMEA), perhitungan Risk Priority Number (RPN) dan Analisa Pareto diperoleh hasil kegagalan yang memperoleh nilai RPN tertinggi yaitu main trolley traveling sistem sebesar 450 dengan breakdown komulatif sebesar $83 \%$.

\section{KESIMPULAN}

Berdasarkan pembahasan dan anlisa hasilpengolahan data yang telah dilakukan pada quayside contianer crane 01 Terminal Nilam Pelabuhan Tanjung Perak, maka dapat disimpulkan sebagai berikut:

1. Berdasarkan hasil analisis kualitatif menggunakan Fault Tree Analysis (FTA) diperoleh 5 (lima) jenis kerusakan dengan probabilitas sebagai berikut :

a. Kerusakan pada supply electrical power sebesar 0,01982361,

b. Kerusakan pada main hoisting sebesar 0,00972778,

c. Kerusakan pada spreader sebesar 0,00312705,

d. Kerusakan pada gantry travel sebesar 0,01343757,

e. Kerusakan pada main trolley traveling sebesar 0,181320537.

2. Berdasarkan hasil analisis kuantitatif menggunakan Failure Mode and Effect Analysis (FMEA) diperoleh nilai Risk Priority Number (RPN) terbesar pada main trolley travelingsystem sebesar 450, kemudian dilanjutkan oleh gantry traveling system sebesar 360, main hoistingsystem sebesar 280, suplying electrical power system 294 dan boom hoistingsystem sebesar 42.

3. Berdasarkan hasil diagram pareto, prosentase komulatif perhitungan breakdown prioritas terdapat pada kerusakan main trolley travelingsystem sebesar 83\%,

4. Berdasarkan hasil analisa perhitungan potensi kehilangan pendapatan, kerusakan yang terjadi pada main trolley traveling system dapatmenyebabkan kerugian sebesar :

Rp. 6.322.201, - x 1341,5 jam = Rp. 8.481.232.642,- (asumsi utilisasi 100\%), 


\section{DAFTAR PUSTAKA}

[1] Lasse.2012. Manajemen Peralatan Aspek Operasional dan Perawatan. Jakarta: PT Rajagrafindo Persada

[2] Wibowo, Febri. 2018. Implementasi Predictive Maintenance Pada Harbour Mobile Crane (HMC). Tugas Akhir. TEKNIK. Teknik Mesin, Universitas Muhammadiyah Surabaya, Surabaya.

[3] Setiawan, Tomy Karunia. 2016. Analisa Kerusakan Pada Gearbox Overhead Crane 10 Ton di PT. INKA (Persero) Madiun dengan Metode Oil Used Analysis. Tugas Akhir. TEKNIK. Teknik Mesin, Insitut Teknologi Sepuluh Nopember, Surabaya. 